\title{
PENGETAHUAN ETIKA AKUNTANSI, RELIGIUSITAS DAN LOVE of MONEY SEBAGAI DETERMINAN PERSEPSI ETIS MAHASISWA AKUNTANSI
}

\author{
Baiq Winda Lestari ${ }^{1}$, Ditya Permatasari2 \\ Universitas Islam Negeri Maulana Malik Ibrahim Malang1,2 \\ Jalan Gajayana No. 50 Malang, 65144, Indonesia \\ e-mail: windabaiq20@yahoo.com ${ }^{1}$
}

\begin{abstract}
This study aims to determine the perceptions of accounting students, about the influence of ethical knowledge, religiosity, and love of money from Islamic-based university.

This research used quantitative research. The technique of data analysis that used to test the hypothesis is simple and multiple regression analysis sample in this study were 151 respondents.Data were collected using a questionnaire.The results of this study indicate that Ethical Knowledge and Religiosity have a positive effect on the Ethical Perceptions of Accounting Students.While Love of Money had a negative effect on the Ethical Perceptions of Accounting Students. From the results of the simultaneous test of Ethics Knowledge, Religiosity, and Love of Money on Ethical Perception of Accounting Students has a simultaneous effect. The higher level of the understanding of their religion, so the level of their money more less than before, vice versa.
\end{abstract}

Keywords: Knowledge of Ethics, Religiosity, and Love of Money and Ethical Perceptions of Accounting Students

\begin{abstract}
Abstrak
Penelitian ini bertujuan untuk mengetahui persepsi mahasiswa akuntansi, tentang pengaruh pengetahuan etika, religiusitas, dan love of money dari perguruan tinggi berbasis agama Islam.Penelitian ini menggunakan jenis penelitian kuantitatif. Teknik analisis data yang digunakan analisis regresi sederhana dan berganda, sampel pada penelitian ini sebanyak 151 responden mahasiswa akuntansi. Data dikumpulkan menggunakan kuisioner.

Hasil dari penelitian ini menunjukkan bahwa Pengetahuan Etika dan Religiusitas berpengaruh positif terhadap Persepsi Etis Mahasiswa Akuntansi. Sedangkan Love of Money berpengaruh negatife terhadap Persepsi Etis Mahasiswa Akuntansi. Dari hasil uji simultan Pengetahuan Etika, Religiusitas, dan Love of Money terhadap Persepsi Etis Mahasiswa Akuntansi berpengaruh simultan. Pengetahuan Etika, Religiusitas, dan Love of Money berpengaruh terhadap Persepsi Etis Mahasiswa Akuntansi. Semakin tinggi tingkat pemahaman agamanya maka tingkat kecintaan nya terhadap uang semakin rendah begitu pula sebaliknya.
\end{abstract}

Kata Kunci: Pengetahuan Etika, Religiusitas, Love of Money dan Persepsi Etis Mahasiswa akuntansi.

\section{PENDAHULUAN}

Manusia merupakan mahluk sosial yang saling bersosialisasi antara satu dengan yang lainnya dimana terdapat suatu niali peraturan yang harus dipenuhi bersama oleh masyarakat. Dalam bersosialisasi sering terjadi permasalahan atau konflik antar individu maupun kelompok. Kondisi seperti ini nilai-nilai etika dapat digunakan untuk mengantisipasi terjadinya permasalahan agar tidak terus menerus dan merugikan banyak orang. Etika merupakan sikap perilaku terhadap pengambilan keputusan untuk menunjukan sikap perilaku benar atau salah. Sehingga etika menjadi sangat penting 
Baiq Winda Lestari dan Ditya Permatasari : Pengetahuan Etika Akuntansi, Religiusitas dan Love Of Money sebagai Determinan Persepsi Etis Mahasiswa Akuntansi

ketika unsur-unsur etis dalam berpendapat antara satu orang dengan yang lainny berbeda.

Persepsi merupakan cara pandang individu mengenai pengetahuan yang telah dimiliki sebelumnya dalam melihat suatu permasalahan. Etika berkaitan pada pertanyaan bagaimana seseorang bertindak terhadap individu lain (Jusup, 2010). Persepsi Etis yaitu bagaimana sistem pengelihatan seorang mahasiswa akuntansi sebagai calon akuntan dengan mengkaitkan pengetahuan dan pembelajaran terhadap etika dari seorang akuntan.

Religiusitas merupakan faktor internal individu dalam menjalankan sebuah perilaku terutama yang berhubungan dengan pengambilan keputusan. Tahap religuitas setiap individu berbeda-beda bergantung pada ketaatan terhadap agama. Jalaluddin (2011) menjelaskan bahwa religuisitas merupakan suatu keadaan atau bentuk sikap keagamaan yang ada pada setiap individu dapat memotivasi untuk berbuat sesuai dengan tingkatan ketaatannya terhadap agama.

Dalam akuntansi mahasiswa akan banyak belajar mengenai sudut pandang keuangan dimana perbincangan selalu berkaitan dengan uang (Jusup, 2010). Seringkali terjadi diskusi dalam perkuliahan maupun di lingkungan sehari-hari sehingga uang menjadi sangat dekat dengan mahasiswa. Pentingnya uang dan interprestasi yang berlainan, Tang (2008) membawa konsep "the love of money" menjadi literatur psikologis yang menjadi bentuk ukuran perasaan subjektif seseorang terhadap uang. Teori Love of money menilai seberapa jauh kecintaan seseorang kepada uang nantinya akan berpengaruh pada persepsi etisnya.

Penelitian ini ingin mengetahui persepsi mahasiswa akuntansi, tentang pengetahuan etika dan love of money dari perguruan tinggi berbasis agama Islam. Pemahaman agama dapat diperoleh mahasiswa dari pengalaman lingkungan pribadi, sosial maupun lingkungan perguruan tinggi. Muatan kurikulum yang diterima mahasiswa pada perguruan tinggi berbasis agama lebih banyak sehingga diharapkan akan memiliki pemahaman agama yang lebih luas dibanding mahasiswa pada perguruan tinggi berbasis non agama. Penelitian ini meperediksi bahwa perbadaan muatan kurikulum agama akan mempengaruh persepsi mahasiswa terhadap etika dan moral.

\section{KAJIAN PUSTAKA}

Etika tidak bisa dipisahkan dari pembahasan moral. Dalam kehidupan etika seringkali dikatakan dengan prilaku etis. Etika berasal dari kata Yunani yaitu ethos yang berarti "karakter"(Elias, 2010) Nama lain dari etika adalah moralitasyang berasal dari bahasa latin yaitu dari kata mores yang berarti kebiasaan. Moralitas berfokus pada prilaku manusia yang "benar" dan "salah". Jadi etika berhubungan denganpertanyaan bagaimana seseorang bertindak terhadap orang lain (Jusup, 2010). Etika sama pengertiannya dengan moral. 
Baiq Winda Lestari dan Ditya Permatasari : Pengetahuan Etika Akuntansi, Religiusitas dan Love Of Money sebagai Determinan Persepsi Etis Mahasiswa Akuntansi

Tabel dibawah ini adalah tingkat orientasi perkembangan moral berdasarkan tingkatan umur:

Tabel 1. Perkembangan Moral Kholberg

\begin{tabular}{|c|c|c|}
\hline Tingkatan & Sublevel & Tahapan Perkembangan Moral \\
\hline $\begin{array}{l}\text { Tingkat.1 } \\
\text { (Preconventional) } \\
\text { Usia }<10 \text { tahun }\end{array}$ & $\begin{array}{l}\text { 1. Orientasi pada hukum } \\
\text { 2. Orientasi pada hadiah }\end{array}$ & $\begin{array}{l}\text { 1. Mematuhi peraturan untuk } \\
\text { menghindari hukum } \\
\text { 2. Menyesuaikan diri untuk } \\
\text { memperolah haiah atau pujian }\end{array}$ \\
\hline $\begin{array}{l}\text { Tingkat.II } \\
\text { (Conventional) } \\
\text { usia 10-13 tahun }\end{array}$ & $\begin{array}{l}\text { 1. Orientasi anak baik } \\
\text { 2. Orientasi otoritas }\end{array}$ & $\begin{array}{l}\text { 1. Menyesuaikan diri untuk } \\
\text { menghindari celaan orang } \\
\text { 2. Mematuhi hukuman dan } \\
\text { peraturan sosial }\end{array}$ \\
\hline $\begin{array}{l}\text { Tingkat.III } \\
\text { (Postcovensional) } \\
\text { usia > } 13 \text { tahun }\end{array}$ & $\begin{array}{l}\text { 1. Orientasi Kontrak } \\
\text { sosial } \\
\text { 2. Orientasi prinsip etika }\end{array}$ & $\begin{array}{l}\text { 1. Tindkan yang dilakssanakan } \\
\text { atas dasar prinsip yang disepakati } \\
\text { bersama masyarakat dan } \\
\text { kehormatan diri } \\
\text { 2. Tindakan yang didasarkan atas } \\
\text { prinsip etika yang diyakini diri diri } \\
\text { sendiri untuk menghindari } \\
\text { penghukuman diri }\end{array}$ \\
\hline
\end{tabular}

\section{Sumber : Makmun (2012)}

Glock dan Stark dalam Ancok (2011) ada lima macam dimensi keagamaan yaitu, (ideologis), dimensi peribadatan atau praktek agama (ritulastik), dimensi penghayatan (eksperensial), dimensi pengalaman (konsekuensial), dimensi pengetahuan agama (intelektual). Dengan berdasarkan pada uraian diatas maka pengukuran religiusitas yang digunakan meliputi: Ukuran kepercayaan atau Akidah Islam, Ukuran Peribadatan atau praktek agama, Ukuran pengalaman atau penghayatan,Ukuran pengetahuan atau ilmu, danUkuran pengalaman atau ahlak

Tang dan Chiu (2003) memakai sekala pandangkecintaan terhadap uang atau The Love Of Money Scale (LOMAS). LOMAS mempunyai empat factor yakni, motivator, sukses, pentingnya uang, dan kekayaan. Love Of Money menggambarkan persamaan pikiran bahwasanya uang adalah motivator, mewakili kesuksesan, uang adalah sangat penting dan keinginan menjadi kaya. Pengukuran LOMS secara subjektif dilakukan melalui perasaan seseorang terhadap uang sedangkan pengukuran objektif dari uang berkaitan dengan sikap atau perilaku orang untuk mendapatkan uang, Tang dan Chiu (2003). Love Of Money digunakan Money Ethics Scale (MES) yang dikembangkan oleh Tang (2003). Sekala ini mengukur sikap manusia terhadap uang.

Elias (2010) berpendapat bahwa mahasiswa akuntansi adalah para professional di masa depan dan dengan pendidikan etika ang baik diharapkan dapat menguntungkan profesinya dalam jangka panjang. Dalam penelitian ini persepsi etis mahasiswa akuntansi adalah proses penginterpretasian dari mahasiswa akuntansi terhadap peristiwa etis yang terjadi. 
Baiq Winda Lestari dan Ditya Permatasari : Pengetahuan Etika Akuntansi, Religiusitas dan Love Of Money sebagai Determinan Persepsi Etis Mahasiswa Akuntansi

\section{HIPOTESIS}

Berdasarkan pada dasar tujuan, penelitian, terdahulu dan kerangka pemikiran teoritis seperti yang telah diuraikan, maka hipotesis yang diajukan dalam penelitian ini adalah:

H1: Pengetahuan Etika berpengaruh positif terhadap persepsi Etis Mahasiswa Akuntansi pada Universitas Islam Negeri Maulana Malik Ibrahim Malang

H2: Religiusitas berpengaruh positif terhadap per persepsi Etis Mahasiswa Akuntansi pada Universitas Islam Negeri Maulana Malik Ibrahim Malang

H3: Love of Money berpengaruh negatif terhadap per persepsi Etis Mahasiswa Akuntansi pada Universitas Islam Negeri Maulana Malik Ibrahim Malang

H4: Pengetahuan Etika, Religiusitas dan Love of Money berpengaruh positif terhadap persepsi Etis Mahasiswa Akuntansi pada Universitas Islam Negeri Maulana Malik Ibrahim Malang

\section{METODE}

Jenis penelitian yang digunakan dalam penelitian ini adalah kuantitatif dengan pendekatan deskriftif. Penelitian ini dilakukan di Universitas Islam Negeri Maulana Malik Ibrahim Malang.

\section{Populasi dan Sampel}

Populasi dalam penelitain ini adalah mahasiswa akuntansi aktif semester 7 dan semester 9 atau dalam tahap akhir perkuliahan karena dalam tahap tersebut mahasiswa sudah dapat pandangan atau persepsi untuk menentukan langkah selanjutnya setelah menyelesaikan seterata satu dijurusan akuntansi.

\section{Metode Pengumpulan Data}

Metode pengumpulan data yang digunakan dalam penelitian ini menggunakan kuesioner (angket) yang disebar melalui googel form.

\section{Pengujian Hipotesis}

Uji hipotesis yang digunakan dalam penelitian ini adalah Regresi Linier Berganda dengan model sebagai berikut:

$$
\mathbf{Y}=\mathbf{a}+\mathrm{b}_{1} \mathrm{X}_{1}+\mathrm{b}_{2} \mathrm{X}_{2}+\mathrm{b}_{3} \mathrm{X}_{3}
$$

Keterangan:

$\mathrm{Y}=$ Persepsi Etis Mahasiswa Akuntansi

$\mathrm{X}_{1}=$ Pengetahuan Etika

$\mathrm{X}_{2}=$ Religiusitas

$\mathrm{X}_{3}=$ Love Of Money

$\mathrm{b}_{1}, \mathrm{~b}_{2}, \mathrm{~b}_{3}=$ Koefisien regresi yang menunjukan angka peningkatan ataupun penurunan variabel dependen yang didasrkan pada perubahan variabel independen.

\section{HASIL DAN PEMBAHASAN}

\section{Analisis data Deskriptif}

Berdasarkan data penyebaran kuesioner sebanyak 151 Mahasiswa Akuntansi Universitas Islam Negeri Maulana Malik Ibrahim Malang yang menerima kuisioner pada semester 9 sebanyak 78 dan semester 7 sebanyak 73 didapatkan hasil sebagai berikut: 
Baiq Winda Lestari dan Ditya Permatasari : Pengetahuan Etika Akuntansi, Religiusitas dan Love Of Money sebagai Determinan Persepsi Etis Mahasiswa Akuntansi

Tabel 2. Rincian Jumlah Pengembalian Kusioner

\begin{tabular}{|c|c|c|c|}
\hline $\begin{array}{c}\text { Angkatan } \\
\text { (Semester) }\end{array}$ & $\begin{array}{c}\text { Kuisioner } \\
\text { Disebar }\end{array}$ & $\begin{array}{c}\text { Kuisioner } \\
\text { Kembali }\end{array}$ & Persentase \\
\hline 2015 (semester 9) & 151 & 78 & $51,7 \%$ \\
\hline 2016 (semester 7) & 151 & 73 & $48,3 \%$ \\
\hline Total & 151 & 151 & $100 \%$ \\
\hline
\end{tabular}

Sumber : Data Primer Diolah 2019

Berdasarkan data kuisioner menunjukan bahwa jenis kelamin laki-laki sebanyak 68 dan perempuan sebanyak 83. Sedangkan untuk usia 20 tahun 20 usia 21-22 sebanyak 117 dan 22> sebanyak 14. Dari keterangan tersebut dapat dijelaskan bahwa Mahasiswa Akuntansi Universitas Islam Negeri Maulana Malik Ibrahim Malng paling banyak diusia 21-22 yang menandakan bahwa pada usia tersebut perseps atau pemikiran sudah matang. Uji Validitas

Berdasarkan hasil SPSS menunjukan bahwa 151 kuesioner yang diterima memiliki nilai signifikansi (sig) dari hasil kuesioner semua variabel lebih keci dari 0,5 atau $\boldsymbol{r}_{\text {hitung }}>$ $\mathrm{r}_{\text {tabel }}$, untuk itu setiap pertanyaan dalam kuesioner dapat dikatakan valid.

\section{Uji Realibilitas}

Berdasarkan hasil SPSS diketahui bahwa nilai Crobach's Alpha dari 5 item pertanyaan yang mengenai Persepsi Etis Mahasiswa Akuntansi sebesar 0,7242. Sedangkan nilai Crobach's Alpha dari 8 item pertanyaan Pengetahuan Etika adalah sebesar 0,8437. Nilai Crobach's Alpha dari 5 item pertanyaan Religiusitas sebesar 0,9052. Nilai Crobach's Alpha dari 10 item pertanyaan mengenai Love of money sebesar 0,9052. Dari semua data hasil Uji Realibilitas disimpulkan bahwa keempat variable pertanyaan penelitian dikatakan reliable dan dapat digunaka dalam penelitian.

\section{Uji Asumsi Klasik}

\section{Uji Normalitas}

Tabel 3. Uji Normalitas Data

\begin{tabular}{|c|c|}
\hline Keterangan & $\begin{array}{c}\text { Unstandardiz } \\
\text { ed Residual }\end{array}$ \\
\hline $\begin{array}{c}\text { Asymp.sig.(2- } \\
\text { tailed) }\end{array}$ &, 707 \\
\hline
\end{tabular}

\section{Sumber : Data diolah 2019}

Berdasarkan hasil dari SPSS dapat diketahui bahwa nilai Asymp. Sig. (2-tailed) sebesar 0,707 yang berarti lebih besar dari 0,05 atau 5\%. Oleh karena itu dapat disimpulkan berdasarkan grafik normal p-plot dan one sample Kolmogorov-smirnov test dapat diambil kesimpulan bahwa data yang digunakan dalam penelitian ini normal dan telah memenuhi uji prasyarat analisis 
Baiq Winda Lestari dan Ditya Permatasari : Pengetahuan Etika Akuntansi, Religiusitas dan Love Of Money sebagai Determinan Persepsi Etis Mahasiswa Akuntansi

\section{Uji Lineritas}

Tabel 4. Hasil Uji Linieritas $X_{1}-Y$

\begin{tabular}{|c|c|}
\hline Keterangan & Sig \\
\hline $\begin{array}{c}\text { Deviation form } \\
\text { Linearity }\end{array}$ &, 179 \\
\hline
\end{tabular}

Sumber : Data diolah 2019

Tabel 5. Hasil Uji Linieritas $X_{2}-Y$

\begin{tabular}{|c|r|}
\hline Keterangan & Sig \\
\hline $\begin{array}{c}\text { Deviation form } \\
\text { Linearity }\end{array}$ &, 170 \\
\hline
\end{tabular}

Sumber: Data diolah 2019

Tabel 6. Hasil Uji Linieritas $\mathbf{X}_{3}-\mathbf{Y}$

\begin{tabular}{|c|r|}
\hline Keterangan & Sig \\
\hline $\begin{array}{c}\text { Deviation form } \\
\text { Linearity }\end{array}$ &, 074 \\
\hline
\end{tabular}

Sumber : Data diolah 2019

Berdasarkan hasil dari SPSS dapat diketahui bahwa hubungan Persepsi Etis Mahasiswa Akuntansi terhadap Pengetahuan Etika memiliki nilai Sig. pada Deviation from linierity sebesar 0,179 yang berarti lebih besar dari 0,05 atau 5\%, hal ini dapat disimpulkan bahwa Persepsi Etis Mahasiswa Akuntansi terhadap Pengetahuan Etika memiliki hubungan linier. Serta hubungan Persepsi Etis Mahasiswa Akuntansi terhadap Religiusitas memiliki nilai Sig. pada Deviation from linierity sebesar 0,170 yang berarti lebih besar dari 0,05 atau 5\%, hal ini dapat disimpulkan bahwa Persepsi Etis Mahasiswa Akuntansi terhadap Religiusitas memiliki hubungan linier. Sedangkan hubungan Persepsi Etis Mahasiswa Akuntansi terhadap Love of Money memiliki nilai Sig. pada Deviation from linierity sebesar 0,074 yang berarti lebih besar dari 0,05 atau 5\%, hal ini dapat disimpulkan bahwa Persepsi Etis Mahasiswa Akuntansi terhadap Love of Money memiliki hubungan linier.

\section{Uji Multikolinieritas}

Tabel 7. Hasil Uji Multikolinearitas

\begin{tabular}{|c|c|c|}
\hline Keterangan & Tolerance & VIF \\
\hline Pengetahuan Etika &, 999 & 1,001 \\
\hline Religiusitas &, 972 & 1,029 \\
\hline Love of Money &, 971 & 1,030 \\
\hline
\end{tabular}

Sumber : Data diolah 2019 
Baiq Winda Lestari dan Ditya Permatasari : Pengetahuan Etika Akuntansi, Religiusitas dan Love Of Money sebagai Determinan Persepsi Etis Mahasiswa Akuntansi

Berdasarkan hasil uji SPSS Coefficients dapat diketahui bahwa variabel Pengetahuan Etika memiliki nilai VIF 1,001 yang artinya lebih besar dari 10 dan Tolerance 0,999 yang lebih kecil dari 0,10, maka dapat disimpulkan bahwa variabel pengetahuan etika tidak ditemukan gejala multikolonieritas. Kemudian variabel Religisusitas memiliki nilai VIF 1,029 yang artinya lebih besar dari 10 dan Tolerance 0,972 yang lebih kecil dari 0,10, maka dapat disimpulkan bahwa variabel religiusitas tidak ditemukan gejala multikolonieritas. Sedangkan variabel love of money memiliki nilai VIF 1,030 yang artinya lebih besar dari 10 dan Tolerance 0,971 yang lebih kecil dari 0,10, maka dapat disimpulkan bahwa variabel love of Money tidak ditemukan gejala multikolonieritas. Maka dapat disimpulkan bahwa ketiga variabel diatas tidak terjadi gejala multikolonieritas atau memenuhi uji asumsi klasik multikolonieritas.

\section{Uji Hetroskedasitas}

Tabel 8. Hasil Uji Hetroskedastisitas

\begin{tabular}{|c|c|}
\hline Keterangan & Sig \\
\hline Pengetahuan Etika &, 146 \\
\hline Religiusitas &, 562 \\
\hline Love of Money &, 759 \\
\hline
\end{tabular}

Sumber : Data diolah 2019

Berdasrkan hasil uji SPSS dapat diketahui bahwa nilai signifikansi pengetahuan etika sebesar 0,146, variabel religiusitas sebesar 0,562 dan variabel love of money sebesar 0,759 , dari ketiga variabel tersebut memiliki nilai signifikansi lebih besar dari 0,05 atau $5 \%$. Oleh karena itu dapat disimpulkan bahwa pada regresi tidak terjadi gejala heteroskedastisitas, yang artinya memenuhi uji asumsi klasik heteroskedastisitas.

\section{Uji Hipotesis}

Uji Regresi Linier Berganda

Tabel 9. Ringkasan Hasil Analisis Regresi Linier Berganda

\begin{tabular}{|l|c|}
\hline \multicolumn{1}{|c|}{ Variabel } & Koefisien \\
\hline $\mathrm{X}_{1}$ &, 111 \\
\hline $\mathrm{X}_{2}$ &, 274 \\
\hline $\mathrm{X}_{3}$ & -.124 \\
\hline Konstan & 8,968 \\
\hline $\mathrm{R}^{2}$ &, 517 \\
\hline $\mathrm{F}_{\text {hitung }}$ & 52,508 \\
\hline $\mathrm{F}_{\text {tabel }}$ & 3,06 \\
\hline Sig &, 000 \\
\hline
\end{tabular}

Sumber: Data diolah 2019

Berdasarkan table diatas dapat diperoleh penjelasan sebagai berikut:

$$
\begin{aligned}
& Y=a+b_{1} X_{1}+b_{2} X_{2}+b_{3} X_{3} \\
& Y=8,968+0,111 X_{1}+0,274 X_{2}+-0,124 X_{3}
\end{aligned}
$$

Bentuk persamaan regresi dari ini menunjukan bahwa nilai $X_{1}, X_{2}$ dan $X_{3}$ konstan atau tidak ada perubahan maka $Y$ akan tetap sebesar 8,968 . Jika nilai $X_{1}$ naik satu satuan 
Baiq Winda Lestari dan Ditya Permatasari : Pengetahuan Etika Akuntansi, Religiusitas dan Love Of Money sebagai Determinan Persepsi Etis Mahasiswa Akuntansi

maka nilai $Y$ naik 0,111 satuan dengan asumsi $X_{2}$ dan $X_{3}$ tetap. Jika $X_{2}$ naik satu satuan maka nilai $Y$ naik sebesar 0,274 satuan, dengan asumsi $X_{1}$ dan $X_{3}$.tetap. Jika $X_{3}$ naik satu satuan nilai $Y$ turun sebesar 0,124 satuan, dengan asumsi $X_{1}$ dan $X_{2}$ tetap.

\section{Uji Parsial (t)}

Hasil dari uji regresi berganda adalah sebagai berikut:

Tabel 10. Uji Parsial (t)

\begin{tabular}{|c|c|c|c|}
\hline Keterangan & $\mathbf{t}_{\text {hitung }}$ & $\mathbf{t}_{\text {tabel }}$ & Sig \\
\hline Pengetahuan Etika & 4,082 & $1,65521$. &, 000 \\
\hline Religiusitas & 5,111 & $1,65521$. &, 000 \\
\hline Love of Money & $-5,226$ & $1,65521$. &, 000 \\
\hline
\end{tabular}

Sumber : Data diolah 2019

Pada tabel diatas dapat diketahui bahwa variabel pengetahuan etika memiliki nilai t sebesar 4,082 dengan nilai signifikansi 0,000, Religisusitas 5,111 dengan nilai signifikansi 0,000 dan love of money -5,226 dengan nilai signifikansi 0,000. Kemudian diperoleh $t$ tabel sebesar 1,65521. Jika dibandingkan maka ketiga variabel tersebut memiliki t hitung yang lebih besar dari t tabel yaitu 1,65521 dan ketiga variabel memiliki nilai signifikansi berada dibawah 0,05 atau $5 \%$. Berdasarkan uji $t$ dan nilai signifikansi maka dapat disimpulkan bahwa :

1. Pengetahuan etika berpengaruh positif dan signifikan secara parsial terhadap persepsi etis mahasiswa akuntansi atau Menerima Ha

2. Religiusitas berpengaruh positif dan signifikan secara parsial terhadap persepsi etis mahasiswa akuntansi atau menerima $\mathrm{Ha}$

3. Love of Money berpengaruh negatif dan signifikan secara parsial terhadap persepsi etis mahasiswa akuntansi atau Menolak Ha

\section{Uji Simultan F}

Hasil dari Uji Regresi Berganda mengenai uji simultan dapat dilihat pada table berikut:

\section{Tabel 11. Uji Simultan (F)}

ANOV A

\begin{tabular}{|c|c|c|c|c|c|c|}
\hline & & $\begin{array}{l}\text { Sum of } \\
\text { Squares }\end{array}$ & $\mathrm{df}$ & Mean Square & $F$ & Sig. \\
\hline \multirow[t]{3}{*}{1} & Regression & 326,769 & 3 & 108,923 & 52,508 &, $000^{a}$ \\
\hline & Residual & 304,940 & 147 & 2,074 & & \\
\hline & Total & 631,709 & 150 & & & \\
\hline
\end{tabular}

a. Predictors: (Constant), Love of Money, Religiusitas, Pengetahuan Etika

b. Dependent Variable: Persepsi Etis Mhs Akuntansi

\section{Sumber: Data diolah 2019}

Berdasarkan tabel diatas dapat diketahui bahwa variabel pengetahuan etika, religiusitas dan love of money memiliki nilai $\mathrm{F}$ hitung sebesar 52,508 dengan nilai 
Baiq Winda Lestari dan Ditya Permatasari : Pengetahuan Etika Akuntansi, Religiusitas dan Love Of Money sebagai Determinan Persepsi Etis Mahasiswa Akuntansi

signifikansi sebesar 0,000. Dan diperoleh nilai $\mathrm{F}$ tabel sebesar 3,06. Jika dibandingkan antara $\mathrm{F}$ hitung dan $\mathrm{F}$ tabel beserta nilai signifikansi yang lebih kecil dari 0,05 atau 5\%, maka dapat disimpulkan bahwa model yang digunakan bagus (fit). Hal ini berarti Pengetahuan Etika, Religiusitas, dan Love of Money terhadap Persepsi Etis Mahasiswa Akuntansi berpengaruh secara signifikan. Oleh karena itu hipotesis ke-empat yang menyatakan bahwa Pengetahuan Etika, Religiusitas, dan Love of Money terhadap Persepsi Etis Mahasiswa Akuntansi diterima.

\section{Uji Koefisien Determinasi $\left(\mathbf{R}^{2}\right)$}

Hasil perhitungan koefisien determinasi Model Summary dapat diketahui bahwa nilai $\mathrm{R}$ Square sebesar 0,517 yang memiliki arti bahwa variabel pengetahuan etika, religiusitas dan love of money mampu mempengaruhi persepsi etis mahasiswa akuntansi sebesar $51,7 \%$ dan sisanya sebesar $48,3 \%$ dijelaskan oleh variabel lain diluar model dapat dilihat pada table berikut:

Tabel 12. Hasil Uji (R2)

Model Summary

\begin{tabular}{|l|r|r|r|r|}
\hline Model & $\mathrm{R}$ & R Square & $\begin{array}{c}\text { Adjusted } \\
\text { R Square }\end{array}$ & $\begin{array}{c}\text { Std. Error of } \\
\text { the Estimate }\end{array}$ \\
\hline 1 &, $719^{\mathrm{a}}$ &, 517 &, 507 & 1,440 \\
\hline
\end{tabular}

a. Predictors: (Constant), Love of Money, Religiusitas, Pengetahuan Etika

\section{Sumber: Data diolah 2019}

\section{Pengetahuan Etika terhadap Persepsi Etis Mahasiswa Akuntansi}

Dari hasil penelitian menunjukan bahwasanya Pengetahuan Etika berpengaruh positif dan signifikan secara parsial terhadap Persepsi Etis Mahasiswa Akuntansi. Penelitian ini ditunjukan dengan hasil analisis regresi sederhana yang menunjukan arah hubungan positif sehingga H1 diterima.

Informasi atau petunjuk yang dimiliki seseorang akan sangat bisa mempengaruhi pengetahuan yang dimiliki. Pengetahuan ini bisa didapatkan dengan mekanisme penerimaan pendidikan formal maupun non formal. Pemahaman akan sangat mendukung untuk mempermudah menyelesaikan suatu permasalah, dan gerakan apa yang harus dilakukan sehingga jalan keluar terbaik yang akan diberikan. Pemahaman Pengetahuan Etika yang dimiliki individu akan menjadi sebuah informasi terkait dengan etika atau aturan yang berlaku. Oleh sebab itu sesorang yang memiliki pemahaman etika tinggi akan berpendapat atau berperilaku sesuai dengan etika yang berlaku. Individu yang memiliki etika akan dapatbereaksi atas tindakan yang tidak etis. Hal ini sesuai dengan teori tahapan perkembangan moral,dimana pada usia 13 tahun, seseorang akan lebih cenderung berorientasi pada etik. Semakin banyak pengetahuan etika yang dimilikioleh mahasiswa akuntansi maka persepsi etis mahasiswa akuntansi akan semakin tinggi.

Keadaan ini sebanding dengan penelitian yang dilakukan oleh Himmah (2013) yang membuktikan bahwa tahap pengetahuan yang dimiliki mempengaruhi persepsi etis auditor dan corporate manager.Maksud dari observasi ini mahasiswa Akuntansi yang 
Baiq Winda Lestari dan Ditya Permatasari : Pengetahuan Etika Akuntansi, Religiusitas dan Love Of Money sebagai Determinan Persepsi Etis Mahasiswa Akuntansi

sebagai responden mempunyai tanggung jawab profesi yang tinggi sedangkan kerahasiananya masih rendah. Menjadi calon akuntan mahasiswa akuntansi harus memilik tanggung jawab profesi yang tinggi dan dapat menjaga kepercayaan sertabekerja sesuai dengan pertimbangan moralnya. Sementara itu mahasiswa akuntansi sebagai calon akuntan yang memilik kepercayaan rendah cenderung kurang menjaga kepercayaan kelaien. Keadaan tersebut akan menjadi sebuah permasalah yang serius karena seorang akuntan harus mempunyai kerahasiaan yang tinggi supaya hasil kerjanya bisa dipercaya oleh orang lain. Saat seorang individu tidak bisa memelihara kepercayaan di akan memanfaatkan informasi yang diadapatkan untuk kepentingan pribadinya yang menyebapkan kualitas kerjanya berkurang sehingga dapat menurunkan kepercayaan terhadap profesi akuntan tersebut.

\section{Religiusitas terhadap Persepsi Etis Mahasiswa Akuntansi}

Hasil dari penelitian ini menunjukan bahwa terdapat pengaruh positif dan signifikan antara variable Religiusitas terhadap Persepsi Etis Mahasiswa Akuntansi. Keadaan tersebut dibuktikan oleh analisis regresi linier sederhana dengan nilai signifikan lebih kecil dari level of significant. Religiusitas yaitu salah satu faktor dari dalam diri individu seberapa sering dan banyak seseorang untuk menjalankan perintah agamanya. Semakin tinggi tingkat Religiusitas maka akan semakin mendoreng kearah berperilaku yang positif yang berarti menjalankan perintahNya dan menjauhi segala laranganNya. Individu yang sudah memilik sifat religiusitas tinggi biyasanya akan lebih cenderung memperhatikan perintah-perintah yang diajarkan agamanya sebagai tolak ukur atau pertimbangan dalam kehidupan sehar-hari dari pada individu yang memiliki tingkat religiusitas yang rendah. Mahasiswa yang menjaga agamanya maka akan lebih memilih berperilaku etis dalam melakukan pekerjaannya atau dalam setiap mengambil keputusan yang akan diambilnya. Hali tersebut karena agamanya yang akan membawa atau menjadi bekal seseorang pada ehidupan dunia maupun akhiratnya kelak.

Hasil penelitian ini sama dengan yang dilakukan oleh Sudibyo (2016). Hasil penelitiannya menunjukan religiusitas berpengaruh terhadap persepsi etis Mahasiswa Akuntansi, sehingga mahasiswa akuntansi yang memiliki religiusitas tinggi terhadap ajaran agama Islam akan berperilaku etis.Dalam penelitian ini menunjukan bahwa mahasiswa akuntansi memiliki keyakinan tinggi kepada Allah SWT sedangkan pengalaman atau penghayatan pada tingkat perasaan dekat kepada Allah SWT masih rendah. Mahasiswa yang mempunyai keyakinan yang lebih tinggi kepada Allah SWT tidak sertamerta membuat mahasiswa tersebut mengalami perasaan dan pengalamanpengalaman religius. Kemungkinan besar mahasiswa masih belum merasakan kehadiraan Allah dalam setiap ibadah masih belum khusuk. Apabila mahasiswa dapat merasakan kehadiran Allah SWT lewat ibadah, do'a, sholat danselalu bersyukur maka mahasiswa akan semakin yakin pada setiap pekerjaan yang dilakukan. Bekerja pula merupakan bagian dari ibadah sehingga dalam setiap aktivitasnya dilakukan karena ingin mendapatkan ridho dari Allah SWT. Seorang akuntan yang dapat mengartikan setiap ibadahnya seharusnya dapat berpikir ulang dalam pengambilan keputusannya agar terhindar dari perilaku yang tidak etis. 
Baiq Winda Lestari dan Ditya Permatasari : Pengetahuan Etika Akuntansi, Religiusitas dan Love Of Money sebagai Determinan Persepsi Etis Mahasiswa Akuntansi

\section{Love of Money terhadap Persepsi Etis Mahasiswa Akuntansi}

Hasil dari penelitian ini menunjukan bahwa terdapat pengaruh negative signifikan antara variable Love of Money terhadap Persepsi Etis Mahasiswa Akuntansi. Hal ini dibuktikan oleh analisis regresi sederhana.Uang berguna untuk mengamati perilaku manusia melalui sikap mereka terhadap uang. Orang-orang yang tidak mencintai uang akan mempunyai perhatian paling rendah untuk kepuasan dan kebutuhan manusia. Tingkat kecintaan mahasiswa Akuntansi terhadap uang cenderung rendah sehingga makin tinggi persepsi etis mahasiswa.

Hal ini sama dengan penelitian yang dilakukan oleh Azis (2015). Hasil penelitian ini menunjukan Love of Money berpengaruh negatif mdan signifikan terhadap Persepsi Etis Mahasiswa Akuntansi.Pada penelitian ini, Mahasiswa Akuntansi memiliki tingkat Budget yang tinggi sedangkan social Influence masih rendah. Mahasiswa akuntansi sebagai calon akuntan yang memeiliki tingkat Budget tinggi terhadap uang akan lebih berhati-hati dalam menggunakan uang. Mahasiswa yang mempunyai budget tinggi berinspirasi bahwa uang untuk kebutuhan sehari-hari dan digunakan untuk jangka panjang. Sementara itu mahasiswa akuntansi sebagai calon akuntan yang memilik social Influence rendah merasa bahwa dengan uang seseorang akan mudah memiliki banyak teman. Mahasiswa menganggap uang adalah segalanya dan menjadi tolak ukur keberhasilan masyarakat. Pandangan seperti ini perlu untuk diperhatikan supaya mahasiswa tidak selalu berorientasi pada uang.

Pengetahuan Etika, Religiusitas, dan Love of Money terhadap Persepsi Etis Mahasiswa Akuntansi

Hasil penelitian ini mendukung hipotesis yang keempat bawa Pengetahuan Etik, Religiusitas, dan Love of Money berpengaruh terhadap Persepsi Etis Mahasswa Akuntansi. Halini ini dapat dilihat melalui nilai koefisien dari uji simultan di nilai table beta. Yang berarti apabila Pengetahuan etika, Religiusitas, dan Love of Money meningkat 1 poin berarti berpengaruh secara simultan terhadap Persepsi Etis Mahasiswa Akuntansi.

Pengetahuan Etika memberikan sebuah informasi terkait dengan etika yang dapat membekali seseorang untuk memberikan penilaian terhadap permasalahan yang terjadi. Religiusitas merupakan factor dalam diri individu terkait ketaatan terhadap agamanya yang dapat mempengaruhi seseorang dalam memberikan atas suatu tanggapan atas keadaan yang dihadapinya. Sedangkan Love of money akan mempengaruhi seseorang dalam menentukan pilihan terkait dengan peristiwa yang dihadapinya. Tetapi berdasarkan dari hasil penelitian pengaruh yang diberikan oleh masing-masing variable independen relative kecil terhadap variable dependen. Hal tersebut dikarenakan oleh factor yang mempengaruhi persepsi seseorang tidak hanya berasal dalam diri seseorang tetapi ada faktor eksternallainya seperti keaadaan sosial, tingkat pendidikan, dan lingkungan yang sangat mempengaruhi sikap individu dalam penelitian ini mampu mengambil keputusan yang akan dilakukannya.

Penelitian ini sama atau sejalan dengan yang dilakukan oleh Himmah (2013). Hasil penelitian menunjukan bahwa Pengetahuan etika berpengaruh terhadap persepsi mahasiswa akuntansi mengenai sekandal auditor dan corporate manager. Penelitian ini 
Baiq Winda Lestari dan Ditya Permatasari : Pengetahuan Etika Akuntansi, Religiusitas dan Love Of Money sebagai Determinan Persepsi Etis Mahasiswa Akuntansi

juga selaras dengan penelitian oleh Bambang (2016) yang menunjukan bahwa religiusitas berpengaruh terhadap persepsi Etis Mahasiswa akuntansi yang memiliki religiusitas tinggi terhadap ajaran agama Islam akan berperilaku etis. Demikian pula dengan penelitian yang dilakukan oleh Azis (2015) menunjukan Love of Money berpengaruh negatife dan signifikan terhadap persepsi etis Mahasiswa Akuntansi.

\section{KESIMPULAN}

Berdasarkan dari hasil penelitian mengenai Pengaruh Pengetahuan Etika, Religiusitas, Dan Love of Money terhadap Persepsi Etis Mahasiswa Akuntansi studi kasus pada Mahasiswa Jurusan Akuntansi Universitas Islam Negri Maulana Malik Ibrahim Malang, dapat diambil kesimpulan bahwa :

Pengetahuan Etika yaitu informasi yang dimiliki seseorang untuk menyelesaikan masalah dan untuk mengambil keputusan berdasarkan pada etika yang berlaku. Hasil penelitian menunjukan bahwasanya pengetahuan etika berpengaruh positif dan signifikan terhadap persepsi etis mahasiswa akuntansi. Semakin banyak dan luas pengetahuan etika yang dimiliki individu makan persepsi etisnya juga akan tinggi. Seseorang yang memiliki pengetahuan etika yang luas akan sangat mudah untuk mengetahui mana yang baik atau tidak. Jadi individu yang memiliki pengetahuan etika yang tinggi lebih cenderung dapat menilai perilaku etis atau tidak.

Religiusitas yaitu tingkat yang dimiliki oleh individu yang dapat mendorongnya untuk bersikap sesuai dengan ketaatatan agamanya. Hasil penelitian ini menunjukan bahwa religiusitas berpengaruh positif dan signifkikan terhadap persepsi mahasiwa akuntansi. Individu yang mempunyai tingkat religiusitas yang tinggi akan lebih berusaha dalam beraktivitas yang dilakukannya berdasarkan pada ajaran agamanya.

Love of money yaitu suatu sikap yang dimiliki seseorang terhadap uang serta keinginan seorang individu terhadap uang. Hasil penelitian menunjukan bahwa Love of money berpengaruh negative signifikan terhadap persepsi etis mahasiswa akuntansi. Tingkat kecintaan uang terhadap mahasiswa akuntansi cenderung rendah sehingga, semakin tinggi persepsi etisnya. Individu yang tidak cinta terhadap uang akan mempunyai perhatian yang paling rendah untuk kepuasan kebutuhan manusia.

Peneliti selanjutnya diharapkan untuk dapat menggunakan responden dari seluruh mahasiswa Jurusan Akuntansi, sehingga hasil penelitian dan digeneralisasi secara luas dan menambahkan variabelnya. Pernyataan kusioner masing-masing variabel yang digunakan masih kurang mendalam untuk membuktikan persepsi etis mahasiswa. Peneliti menyarankan untuk lebih menggali lagi pernyataan pada variabel Persepsi Etis Mahasiswa Akuntansi dengan sekenario yang dapat disesuaikan dengan Standar kode etik Profesi akuntan. Pada variabel Religiusitas untuk memberikan pernyataan yang lebih mendalam atau menyesuaikan dengan konteksnya begitu pula pada variabel pengetahuan etika dan Love of Money.

\section{DAFTAR PUSTAKA}

Agoes Sukrisno dan Ardana Cenik, I. (2009). Etika Bisnis dan Profesi (tantangan membangun manusia seutuhnya). Jakarta: Salemba empat. 
Baiq Winda Lestari dan Ditya Permatasari : Pengetahuan Etika Akuntansi, Religiusitas dan Love Of Money sebagai Determinan Persepsi Etis Mahasiswa Akuntansi

Al-Qur'an Karim Terjemahaan dan As Sunnah

Ancok Djamaludin dan Suroso Nashori, F. (2011). Psikologi Islami. Yogyakarta: Pustaka Pelajar

Bertens. (2013). Etika. Yogyakarta: Kanisius

Chen, Y.J. dan Tang, T.L.P. 2006. "Attitude toward and propensity to engage in unethical behavior: measurement invariance across major among university students", Journal of Business Ethics, Vol. 69, pp. 77-93.

Elias, R. Z. (2009). The Impact of Anti-Intellectualism Attitudes and Academic Self Efficacy on Business Students' Perceptions of Cheating. Journal ofBusiness Ethics, 86, 199-209. New York: Springer.

Fiqoh Himmah Elok. (2013). Persepsi Etis Mahasiswa Akuntansi Mengenai Skandal Etis Auditor dan Corporate Manager. Jurnal Akuntansi Multiparadigma. Malang

Ghozali Imam. (2011). Aplikasi Analisis Multivariate dengan Program SPSS. Semarang: Universitas Diponogoro

Gulo W. (2010). Metodologi Penelitian. Jakarta: PT Gramedia Widiasarana Indonesia

Hadi Sutrisno. (2001). Statistik. Yogyakarta : Andi Offset

Hayes, J. V. (2006). "Money Attitudes Economic Locus of control and Financial Strain Among College Students." A Disertation. Texas Tech University

Jalaluddin. (2011). Psikologi Agama. Jakarta:Rajawali

Jusuf Al Haryono. (2010). Pengauditan. Yogyakarta: Sekolah Tinggi Ilmu Ekonomi YKPN

Kent T. Yamuchi and Donald I. Templer. (1982). The Development of a Money Attitude Scale. Jurnal of Personality, 46,5

King A. Laura. (2013). Psikologi Umum. Jakarta :Salemba Humanika

Lubis Ikhsan Arfan. (2011). Akuntansi Keperilakuan. Jakarta: Salemba Empat

Lubis, dan Al dan Ishak, M. (2005). Akuntansi Keperilakuan.Jakarta: Salemba Empat

Madison, R.L. (2002), "Is failure to teach ethics the causal factor?", Strategic Finance, Vol. 84 , pp. 24-6.

Muchlas Makmuri. (2008). Perilaku Organisasi. Yogyakarta: Gajah Mada University Press

Nopirin. (2014). Ekonomi Moneter. Yogyakarta: BPFE

Revita Mardawati. (2014). Pengaruh orientasi etis, gender, dan pengetahuan etika terhadap persepsi mahasiswa akuntansi atas perilaku tidak etis akuntan (studi 
Baiq Winda Lestari dan Ditya Permatasari : Pengetahuan Etika Akuntansi, Religiusitas dan Love Of Money sebagai Determinan Persepsi Etis Mahasiswa Akuntansi

pada mahasiswa akuntansi universitas negeri yogyakarta). Yogyakarta: Skripsi Universitas Negeri Yogyakarta.

Sugiyono. (2011). Metode Penelitian Kuantitatif, Kualitatif, dan RED. Bandung: Alfabeta. (2012). Statistik untuk penelitian. Bandung. Alfabeta

Tang, T.L.P. and Chen,Y.J. (2008). "Inteleligence vs Wisdom: The love of Money, Machiavellianism and Unethecial Behavior Across College Majorand Gender". Journal ofBusiness And Ethic, Vol 82, pp. 1-26.

Tang, T.L.P. and Chiu, R.K.. (2003). “Income Money Ethic, Pay, Satisfaction, Commitment, and Unethical Behaviour: Is the Love of Money The Root of Evil for Hongkong Employees ?",Journal Business Ethic, Vol. 46, pp. 542-8.

Tang, Thomas Li-Ping., David Shin-Hsiung Tang, \& Roberto Luna-Arocas. (2005). "Money Profiles: The Love of Money, Attitudes, and Needs". Personnel Review, Vol. 34 Iss pp.603-618

Walgito Bimo. (2007). Psikologi Kelompok. Yogyakarta: Andi

Wati Mirna dan Sudibyo Bambang. (2016). Pengaruh pendidikan etika bisnis dan religiusitas terhadap persepsi etis mahasiswa akuntansi. Yogyakarta: Jurnal Universitas Gadjah Mada

Wilujeng, Kristianingsih. (2013). Pengaruh Self Efficacy dan Religiusitas Terhadap Academic Dishonesty yang dilakukan mahasiswa Perguruan tinggi Umum dan Berbasis Agama di Kota Malang. Universitas Negeri Malang. 